\title{
GLI1 wt Allele
}

National Cancer Institute

\section{Source}

National Cancer Institute. GL11 wt Allele. NCI Thesaurus. Code C52931.

Human GLI1 wild-type allele is located within 12 q13.3 and is approximately $12 \mathrm{~kb}$ in length. This allele, which encodes zinc finger protein GLI1, is involved in the modulation of transcription by RNA polymerase II and the regulation of the transcription of specific genes during the development of multiple organ systems. 